\title{
Health-associated infections and COVID-19 in Mexico: safety and health rules at work or job biosecurity?
}

\author{
Ruiz MR ${ }^{1}$, Villeda GJD², Mendez DA ${ }^{3}$
}

${ }^{1}$ Internist and Nephrologist Medical Center ISSEMyM Toluca, Mexico, ${ }^{2}$ Metropolitan Autonomous University-I. CDMX. Research Fellow level V. U INVEST MED IN BIOQUIM, Hospital de Especialidades Medical Dr. Bernardo

Sepúlveda Gutiérrez, CMN S XXI. IMSS. Mexico City, ${ }^{3}$ Adult Nephrologist. Arterial Hypertension Specialist.

Diabetes Specialist. Coordinator of Medical Programs. Coordination of Medical Infrastructure Planning.

Directorate of Medical Benefits of the Mexican Institute of Social Security. Central level. Mexico City, Mexico.

\section{ABSTRACT}

The pandemic caused by COVID-19 has grown exponentially from the first reports from China in December 2019 to November 2020. Cases have been reported in more than 180 countries, totaling more than 61.8 million cases of COVID-19 throughout the world and more than 1.4 million deaths. Health personnel, being exposed to the care of COVID-19 patients with high viral load, have the risk of developing infections associated with health care, their high morbidity and mortality being of multifactorial origin. Given that the term Biosafety and Occupational Biosafety has been used internationally, this term does not have wide acceptance in the scientific community, and the case of Mexico is not referred to and is not defined in the Mexican legal framework or current regulations. Far from being handled and understood as an isolated concept, this term should be referred to as a multiple concepts, being recommended in the workplace in Mexico not to use it, suggesting referring to the Safety and Health Regulations at Work, whose mandatory application will allow reducing healthcare-associated infections.

Key words: COVID-19, Health-associated infections, Health personnel, Job biosecurity, Safety and health rules at work

\section{Introduction}

$\mathrm{H}$ ealth care-associated infections (HCAls) have been recognized for more than a century as a critical problem that affects the quality of health care of the population treated in the hospital environment. It has been shown that up to one-third of Infections associated with healthcare can be avoided. ${ }^{1}$

HCAls have traditionally been focused on hospitalized patients and are defined as an infection contracted in the hospital by an inpatient for a reason other than that infection, including infections that occur even after 48

Date of submission: 21.01.2021

Date of acceptance: 19.04.2021

\section{Corresponding Author}

Ramón Ruiz Mejia

Av. Baja Velocidad No 284 San Jerónimo Chicahualco

Metepec. Edo. Méx. C.P. 52170 Phone 7222756300

E-mail: ramonrm78@outlook.com

Phone: 7221825587

ORCID ID: https://orcid.org/0000-0001-9953-1175 hours of hospitalization. ${ }^{2}$ This definition also includes occupational infections contracted by health personnel in association with one or more cases of nosocomial infection, the position at risk of contracting the infecting agents. $^{3}$

The Atlanta Center for Disease Control and Prevention (CDC) in the United States refers to Healthcare Personnel as all persons who work in health care settings who have the potential to be exposed to patients and/or infectious materials, including Contaminated bodily substances, medical supplies, and equipment, contaminated environmental surfaces, or contaminated air. ${ }^{4}$

In 1987, the Center for Disease Control and Prevention issued a series of recommendations known as Universal Precautions. ${ }^{5}$ These are based on considering blood and other bodily fluids as potentially infectious by not

\section{c) (i) (8)}

This journal is licensed under a Creative Commons AttributionNon Commercial 4.0 International License. 
knowing the infection status of the patients; these recommendations include the use of barrier protection elements (use of protective gloves, masks, protective glasses, gowns or aprons), hand washing, the correct handling of sharp objects with their correct disposal and the standard procedures of sterilization and disinfection.

Since 2007, Mexico has taken as a reference the guidelines established by the World Health Organization (WHO) for patient safety, establishing the Essential Actions for their Safety. ${ }^{6}$ However, as with Universal Precautions, despite the benefit shown in some hospital activities, these actions have found limitations for compliance in two figures: the first in health personnel, who shows skepticism, lack of knowledge and training, lack of time, work overload, little availability of supplies and inadequate infrastructure, little dissemination of information in health facilities, lack of integration and participation at different levels; and the second, in those responsible for the establishments or those responsible for the different institutions. ${ }^{6}$

With the COVID-19 pandemic, more than 70,000 deaths have been reported in Mexico in the general population, despite strategies to prevent its spread; thus, concerning the 97,632 health personnel infected from February to August 2020, 1,320 deaths have been registered until September of this year, surpassing other countries such as the United Kingdom and the
United States of America, standing out as causes of these deaths among others: the lack of personal protective equipment, work with informal contracts that limit social security, occupational exposure in public and private institutions, as well as comorbidities in health personnel ${ }^{7}$. So far, various reports have been published describing the total population infected by SAR COV 2, breaking down the total number of cases or, where appropriate, the percentage of health care workers infected. (Table 1)

Since the beginning of the 21st century, the rapid development in the field of biotechnology has changed the mode of research and promoted the development of biosafety technology: for some years now, pathogens and toxins have been used in basic and applied research, in quality control, in pharmaceutical research and development, in food manufacturing and production, among others. ${ }^{14}$ Because much of the research in this area involves the study of microbial pathogens, there is a potential risk of infection for researchers in the laboratory and additionally, that these pathogens may escape the laboratory and pose a risk to public health. ${ }^{15}$

By definition, laboratory biosafety is the term used to describe the principles, technologies, and containment practices that are implemented to prevent inadvertent exposure to pathogens and toxins or their accidental release, while laboratory biosecurity are measures

Table 1: SARS-CoV-2 infection in health care workers

\begin{tabular}{|c|c|c|c|}
\hline Author & $\begin{array}{l}\text { Number of cases } \\
\text { Health workers affected }\end{array}$ & $\begin{array}{l}\text { Median age } \\
\text { (years) }\end{array}$ & Comorbidities \\
\hline Agren D. ${ }^{7}$ & 97,632 health care workers infected & Not reported & Not reported \\
\hline Pan et al. ${ }^{8}$ & $\begin{array}{l}32583 \text { cases } \\
1496 \text { health care workers } \\
\text { (4.6\% of all cases) }\end{array}$ & 56.7 & Not reported \\
\hline Burrer SL et al. ${ }^{9}$ & $\begin{array}{l}315,531 \text { covid- } 19 \text { cases } \\
9,282 \text { health care personal } \\
\text { (19\% of all cases) }\end{array}$ & 42 & $\begin{array}{l}\text { Preexisting medical } \\
\text { conditions and other risk } \\
\text { factors }\end{array}$ \\
\hline Boccia et al. ${ }^{10}$ & 8920 health care personal & 80 & Not reported \\
\hline Wang $D$ et al. ${ }^{11}$ & $\begin{array}{l}138 \text { cases } \\
40 \text { health care workers } \\
\text { ( } 29 \% \text { of all cases) }\end{array}$ & 56 & $\begin{array}{l}\text { Hypertension } 43 \% \\
\text { Cardiovascular disease } 14 \% \\
\text { Diabetes } 10 \%\end{array}$ \\
\hline Zhan M. ${ }^{12}$ & $\begin{array}{l}77,262 \text { patients with covid-19 } \\
3387 \text { health care workers } \\
\text { ( } 4.4 \% \text { of all cases) } \\
23 \text { health care workers died }\end{array}$ & 55 & Not reported \\
\hline Guerrero T. et al. ${ }^{13}$ & $\begin{array}{l}125,665 \text { confirmed sars-cov- } 2 \text { cases } \\
16446 \text { health care workers } \\
(13.1 \% \text { of all cases) }\end{array}$ & 38 & $\begin{array}{l}\text { Obesity } \\
\text { Hypertension } \\
\text { Diabetes }\end{array}$ \\
\hline
\end{tabular}


of institutional and personal security designed to prevent the intentional loss, theft, misuse, diversion, or release of pathogens and toxins; therefore, the WHO has established that biological hazards include both accidental (biosafety) and deliberate (biosafety) risks. ${ }^{16}$

In 2012, the Biosecurity Challenges of the Global Expansion of High-Containment Biological Laboratories workshop was held, whose objective was to involve scientific experts, who proposed, among other points, strategies to improve biological security and protection throughout the world. world. In this report, the term biosecurity was used to refer to measures aimed at reducing the deliberate misuse of biological materials or biotechnology, while the term biosafety referred to protecting laboratory workers, community members, and the environment from accidental exposure to pathogens. ${ }^{17}$

The coronavirus disease 2019 (COVID-19) outbreak in December 2019 highlighted several points regarding hospital biosecurity training in the People's Republic of China, highlighting the importance of biosecurity. ${ }^{18}$ Due to the previous concept, in the workplace, some publications refer to using the term Biosafety focused on health personnel, the purpose of which is to allow the identification and control of the biological risks to which all health personnel is exposed..$^{19}$

\section{Biosecurity: Definition and Background}

Biosafety is a term whose definition is not widely accepted in the international community ${ }^{19}$, due to the absence of a consensus between the different entities and responsible organizations, since it is used in areas as diverse as food, agriculture, medicine, biotechnology, and terrorism.

Various entities and organizations have defined the term Biosecurity within their areas:

a) Derived from the precautionary approach contained in the Rio Declaration on Environment and Development, the Cartagena Protocol on Biosafety of the Convention on Biological Diversity ${ }^{20}$ was created, the objective of which was:

1. Ensure an adequate level of protection in the area of the safe transfer, handling, and use of living modified organisms resulting from modern biotechnology that may have adverse effects on the conservation and sustainable use of biological diversity.
2. Consider the risks to human health, with a specific focus on transboundary movements.

It is in this Cartagena Protocol where the term Biosafety (Biosafety) is defined, a concept that concerns the need to protect human health and the environment against possible adverse effects of biotechnology products; In other words, it describes it as the prevention of biotechnological risks in the different areas that affect human life, the human being the ultimate object. ${ }^{21}$

b) The Food and Agriculture Organization of the United Nations $(F A O)^{22}$ describes the English terms Biosecurity and Biosafety, posing a problem for the translation into Spanish and French since they have both been translated by Bioseguridad. The publication defines the term Biosecurity as Biosafety and the term Biosafety as Bio-safety.

c) In the United States, the term Biosecurity originally described efforts to prevent infectious diseases in crops and livestock, particularly poultry. ${ }^{23}$ As such, it included measures that can or should be taken to prevent disease (viruses, bacteria, fungi, protozoa, parasites) from a farm and to prevent disease transmission (by humans, insects, rodents, and wild birds/animals) within an infected farm to neighboring farms. ${ }^{24}$

d) For NASDA (National Association of State Departments of Agriculture) Biosecurity includes planning, effort, and strategy to protect humans, animals, and the environment against biological threats; it is, therefore, the sum of risk management practices in defense against biological threats. ${ }^{25}$

e) The WHO in its 3rd edition of the Laboratory Manual ${ }^{16}$ refers to the terms Biosafety / Biosecurity as Biological Safety / Biological Protection:

- Biosafety (Biological Safety or Biosafety): Term used to refer to the principles, techniques, and practices applied to avoid unintentional exposure to pathogens and toxins or their accidental release.

- Biosecurity (Biological Protection, Bio protection, or Biosafety) refers to the protection measures of the institution and of the staff, aimed at reducing the risk of loss, theft, incorrect use, deviations, or intentional release of pathogens or toxins.

f) The European Committee for Standardization ${ }^{26}$ defined the terms Biosafety / Biosecurity in Laboratory:

- Biosafety (Biosecurity). Those principles, techniques, and practices are applied to avoid 
unintentional exposure to pathogens and toxins or their accidental release.

- Biosecurity (Biosecurity). The security describes the protection, control, and accountability of biological agents and toxins in laboratories, to prevent their loss, theft, misuse, diversion, unauthorized access, or intentional unauthorized disclosure.

g) In 2019 Zou defines biosecurity (biosafety/ biosecurity are called biosafety $)^{27}$ as the ability of a country to respond effectively to biological threats and related factors and includes: prevention and control of the main emerging infectious diseases, defensive action against biological weapons attacks, prevention of bioterrorism attacks, prevention of abuse of biotechnology, protection of laboratory biosafety, protection of special biological resources and prevention of invasion of extraterrestrial organisms.

In the area of medicine and related sciences, it is necessary to control and identify all risks related to the health and safety of health personnel, exponentially reducing the rate of risks and incidents of any kind; within these risks, the biological risk is defined as the probability of occurrence of an adverse event that involves exposure to biological agents or toxins and its consequences in terms of accidental infection, toxicity or allergy.

Because healthcare personnel are exposed to multiple occupational risks, general and universal measures aimed at avoiding biological risks in the healthcare environment are essential; It is worth mentioning that the regulations define the terms worker and do not describe the term biosafety in them.

\section{Safety and Health at Work: Regulatory Framework in Mexico}

Health and Safety at work in Mexico are regulated by the contents of the Political Constitution of the United Mexican States, the Federal Labor Law Article 123 section "A", the Federal Law of Workers at the Service of the State section "B", the Organic Law of the Federal Public Administration, the Federal Law on Metrology and Standardization, the Federal Regulations on Safety and Health at Work, the Federal Regulations on Safety, Hygiene and Work Environment and by various official Mexican standards that apply in the matter; This is based on Article Four of the Political Constitution of the United Mexican States that establishes the right of everyone to health protection. ${ }^{28}$
In the first place, the Political Constitution of the United Mexican States ${ }^{29}$ stipulates in general terms in its articles 5 and 123 section " $A$ " the following:

- No person may be prevented from engaging in the profession, industry, trade, or work that suits them, being lawful.

- The employer will be obliged to observe, following the nature of his negotiation, the legal precepts on hygiene and safety in the facilities of his establishment, and to adopt the appropriate measures to prevent accidents in the use of the machines, instruments, and materials of work, as well as to organize it in such a way that it is the best guarantee for the health and life of the workers.

Second, the Federal Labor Law ${ }^{30}$ defines the Worker as the natural person who lends to another, physical or moral, subordinate personal work and the Employer as the natural or legal person who uses the services of one or more workers; This law establishes the need to have optimal safety and hygiene conditions to prevent occupational risks, disseminating information on the risks and dangers to which workers are exposed, disseminating regulations and official Mexican standards on safety, health and safety. work environment, to increase productivity, improving the educational level, labor competence and skills of workers.

Third, the Federal Regulation on Safety and Health at Work ${ }^{31}$ establishes the power of the Ministry of Labor and Social Welfare to issue Standards based on the Federal Law on Metrology and Standardization and its regulations and the Federal Labor Law, to establish provisions on safety and health at work that avoid risks that endanger the life, physical integrity or health of workers, and adverse and substantial changes in the work environment that affect or may affect safety or health of workers or cause damage to facilities, machinery, equipment and materials in the workplace.

Fourth, the Federal Law on Metrology and Standardization $^{32}$ determines the competence of different agencies to issue Official Mexican Standards related to their attributions, whose purpose is to establish the health, safety, and hygiene conditions that must be observed in the work centers, as well as the process of elaboration, modification, and publication of these.

Fifthly, to monitor and operate the functions determined by both the constitutional article 123 and the Federal 
Labor Law, the Federal Executive Power, for the dispatch of administrative matters, has the Ministry of Labor and Social Welfare ${ }^{33}$ dependency with the following functions:

- Base its activities in accordance with the national objectives, strategies, priorities, and programs contained in the National Development Plan, the respective sectoral program, and the policies established by the President of the Republic, in coordination with other agencies and entities of the Federal Public Administration.

- To oversee the performance of the powers attributed to it by the Organic Law of the Federal Public Administration, the Federal Labor Law, other laws and treaties, regulations, decrees, agreements, and orders of the President of the Republic.

- To oversee designing, executing, and coordinating public policies regarding job creation, contractual relations, worker groups, labor rights, and social rights.

Sixthly, the Official Mexican Standards are mandatory technical regulations issued by the competent agencies, the purpose of which is to establish the characteristics that processes or services must meet when they constitute a risk to the safety of people or can damage human health. The Ministry of Labor and Social Welfare ${ }^{34}$ issues the Official Mexican Standards that determine the minimum conditions necessary for the prevention of occupational hazards and are characterized by the fact that they are used to address risk factors to which workers may be exposed; different Official Mexican Standards on Occupational Health and Safety are described, grouped into five categories: safety, health, organization, specific and product, being their mandatory application throughout the country. (Table 2)

Table 2: Official Mexican Standards with mandatory application in work centers.

\begin{tabular}{|c|c|}
\hline $\begin{array}{l}\text { OFFICIAL MEXICAN } \\
\text { STANDARD: SECURITY + } \\
\text { E28D43D5:E26D5D5:E26 }\end{array}$ & $\begin{array}{l}\text { STANDARD } \\
\text { NUMBER }\end{array}$ \\
\hline $\begin{array}{l}\text { Buildings, premises and } \\
\text { facilities }\end{array}$ & NOM-001-STPS-2008 \\
\hline $\begin{array}{l}\text { Prevention and protection } \\
\text { against fire }\end{array}$ & NOM-002-STPS-2010 \\
\hline $\begin{array}{l}\text { Safety systems and devices } \\
\text { in machinery }\end{array}$ & NOM-004-STPS-1999 \\
\hline
\end{tabular}

Handling, transport and storage of dangerous

NOM-005-STPS-1998

substances

Materials handling and

storage

Work at height

NOM-006-STPS-2014

NOM-009-STPS-2011

Pressure vessels and boilers NOM-020-STPS-2011

Static electricity 2008

NOM-022-STPS-2008

Static electricity 2015

NOM-022-STPS-2015

Welding and cutting

NOM-027-STPS-2008

Maintenance of electrical

installations

NOM-029-STPS-2011

Work in confined spaces

NOM-033-STPS-2015

Access and development

of activities for workers with NOM-034-STPS-2016

disabilities

OFFICIAL MEXICAN

STANDARD: HEALTH

Chemical contaminants

NOM-010-STPS-1999

Noise

NOM-011-STPS-2001

lonizing radiations

NOM-012-STPS-2012

Non-ionizing radiations

NOM-013-STPS-1993

Abnormal environmental

NOM-014-STPS-

pressures

2000

High or low thermal

conditions

NOM-015-STPS-2001

Vibrations

NOM-024-STPS-2001

OFFICIAL MEXICAN

STANDARD:

ORGANIZATION

Personal protection

equipment

NOM-017-STPS-2008

Identification of hazards

and risks due to chemical

NOM-018-STPS-2000

substances

Safety and hygiene

commissions

NOM-019-STPS-2011

Colors and safety signs

NOM-026-STPS-2008

Safety in processes and

equipment with chemical

NOM-028-STPS-2012

substances

Preventive health and safety

services

NOM-030-STPS-2009

OFFICIAL MEXICAN

STANDARD: SPECIFIC

Pesticides and fertilizers

NOM-003-STPS-1999

Agricultural facilities,

machinery, equipment and NOM-007-STPS-2000

tools

Timber forest use

NOM-008-STPS-2013 
Railway operation and

maintenance

NOM-016-STPS-2001

Work in underground and

open pit mines

NOM-023-STPS-2012

Building

NOM-031-STPS-2011

OFFICIAL MEXICAN

STANDARD: OF PRODUCT

Fir fighting equipment

NOM-154-SCFI-2005

Personal protective

equipment protective

NOM-113-STPS-2009

footwear

Seventh, the Federal Regulations on Safety, Hygiene and Work Environment ${ }^{35}$ establish the necessary measures for the prevention of accidents and occupational diseases, aimed at ensuring that the provision of work is carried out in adequate safety, hygiene, and environmental conditions. for workers, per the provisions of the Federal Labor Law, section A. In this same regulation, the term Personal Protective Equipment is defined, referring to the set of elements and devices specifically designed to protect the worker against Accidents and Occupational Diseases.

\section{International Standards}

At the international level, Occupational Health and Safety Standards are known as OHSAS 4500136 (Occupational Health and Safety Assessment Series) have been created, which define the Worker as that person who performs work-related activities that are under the control of the organization and allow implementation correctly and effectively the management of risks and the health of workers, allowing organizations and companies to achieve a series of benefits to increase their productivity and improve their image both internally and externally, with the following benefits :

- Decrease in work incidents, through the identification, evaluation, analysis, and control of the risks associated with each job, which increases the profitability and productivity of organizations and companies.

- Perception of a safer environment by workers and stakeholders.

\section{The Term Biosecurity in Mexico}

In México, unlike other countries, the term Biosafety is generally applied at the laboratory, research level, and in the Law of Genetically Modified Organisms, specifying the principles, technologies, and containment or confinement practices implemented to prevent non-exposure. to biological agents and toxins, or their accidental release. The following institutions apply the term Biosecurity:

1. The General Hospital of México. It has promoted research and with it, the regulation and formal registration of research protocols, for which it created the Research Biosafety Committee and this, in turn, has published a Manual of Biosafety Procedures, which establishes the policies, norms, and mechanisms for issuing a technical opinion on the biosafety aspects of investigations, complying with the guidelines established by the Regulation of the General Health Law on Research Matters. ${ }^{37}$

2. The Autonomous University of Yucatán, who focuses the term Biosafety in research processes, due to the risks of contagion and diseases for researchers, students, and visitors to the Centers or Institutes dedicated to this activity, constituting in 2010 the Committee of Biosafety through the Dr. Hideyo Noguchi Regional Research Center. ${ }^{38}$

3. The National Institute of Public Health, who through the Biosafety Committee has created the Internal Regulations of the Biosafety Committee, granting it the responsibility of issuing a technical opinion on the biosafety aspects of the proposed investigations, to guarantee the safeguarding the physical and biological integrity of occupationally exposed personnel, as well as research subjects, the community, and the environment. ${ }^{39}$

4. The National Institute of Respiratory Diseases Ismael Cosió Villegas. Who, through the Biosafety Committee, has created the Integration and Operation Manual of the Biosafety Committee, which in turn is in charge of regulating the use of ionizing radiation and genetic engineering techniques within the establishment, to guarantee the safeguarding the physical and biological integrity of occupationally exposed personnel, research subjects, the community and the environment. ${ }^{40}$

5. The National Council of Science and Technology (CONACYT) through the Technical Committee, aims to support Comisión Intersecretarial de Bioseguridad y Organismos Genéticamente Modificados (CIBIOGEM) in the development of its functions and in the fulfillment of its purpose, in terms of the provisions of the Biosafety Law of Genetically Modified Organisms. ${ }^{41}$

6. The Mexican Biosafety Association A.C. Being a group of non-profit professionals formed in 2009, 
after the epidemic outbreak of AH1N1 influenza, training personnel trained in the proper handling of biological-infectious materials, biological safety, and the safe handling of genetically modified organisms (GMOs). ${ }^{42}$

7. The Dr. Manuel Martínez Báez Institute of Epidemiological Diagnosis and Reference $(\text { InDRE })^{43,44}$ is the institution dependent on the Secretary of Health of Mexico, in charge of diagnosis, control, reference, research, and technological development for the surveillance of epidemiological diseases, whose function is to serve as a National Reference Laboratory, carrying out surveillance and diagnostic tests for a wide spectrum of agents and diseases. InDRE's collection of technical publications includes among others:

- Biosafety and custody protocol for the management of patients during the collection of samples of suspected cases of the disease by $2019-n C o V$.

- Guidelines for laboratory surveillance of dengue, arbovirus, Chagas disease, Human Immunodeficiency Virus, Tuberculosis, brucellosis, acute bacterial diarrheal disease, rickettsiosis, whooping cough, bacterial acute respiratory infections, feverish exanthemantic disease, influenza and other respiratory viruses, rabies, acute flaccid paralysis, malaria, leishmaniasis, viral hepatitis, syphilis and other sexually transmitted infections, cervical cancer.

- Guidelines for the management of biological risk.

- Guidelines for taking, handling, and sending samples for diagnosis to the National Network of Public Health laboratories.

There is no specific definition of occupational risk associated with health, much less the term labor biosecurity in México, since the various instances and agencies, based on current legal regulations, establish the mandatory regulations that determine the minimum conditions necessary for the prevention of occupational hazards in general.

\section{The situation of Sanitary Personnel in Mexico}

Health personnel is more likely than other groups to have work-related injuries or illnesses since the probability of having a sick leave due to work-related injuries or illnesses is more than $40 \%$ compared to other groups of workers. ${ }^{45}$
In the Region of the Americas, as of August 28, 2020, a total of $13,005,995$ cases were reported, including 458,444 deaths in the 54 countries/areas/territories of the Region. The highest proportion of cases were reported in the United States of America (45\%) and Brazil (29\%), while the highest fatality rates were observed in Canada (7.2\%), Ecuador (5.8\%), and Mexico $(10.8 \%){ }^{46}$

In Mexico, the State Center for Epidemiological Surveillance and Disease Control identified that one of the greatest risks to the health system is a high rate of severe acute respiratory syndrome due to SARSCoV-2 among health personnel and the consequent lack of trained staff to ensure an adequate local or regional response, increased risk by the need to rapidly increase the capacity of intensive care units, redeployment of clinical staff to front-line positions, hiring less experienced staff into the workforce, to the lack of protective supplies such as N95 masks, to poor training and insufficient training so that health personnel know how to take care of themselves and prevent contagion, among others; This has determined that the rate of infection by the SARS-Cov-2 virus among health personnel is six times higher than in China and twice that in Italy; detecting a fatality rate five times higher than in the United States. ${ }^{46}$

As of November 4, 2020, a total of 140,196 cases of health personnel in Mexico have been confirmed as positive for COVID.19, being $61 \%$ of the cases of the female sex with ages of 30 to 49 years, being confirmed 1884 deaths of which $70 \%$ were male..$^{47}$

Globally until November 29, 2020, about 61.8 million cases and approximately 1.4 million deaths have been reported since the beginning of the pandemic. ${ }^{48}$

\section{Gaps and Challenges in Biosafety}

With the changes in the international security situation, the progress of globalization, and the continuous advance of technology, the risks, and challenges posed by the main infectious diseases and bioterrorism in the international community have increased in parallel. Biosecurity, therefore, presents new opportunities for international cooperation and global governance. It is a fact that the world has become more integrated and is now heading for a common destiny in terms of biosecurity. Faced with current challenges, the international community must work together to reduce and avoid biological threats, safeguarding global 
biosecurity. ${ }^{27}$ In recent years, the biological risks of emerging infectious diseases worldwide, bioterrorism, and biological invasion are increasing, so in 2018, the First World Symposium on Biosafety was held in Beijing, focusing on biosafety. (biosafety) and biosafety (biosecurity), in the monitoring and early warning of infectious diseases, the control of imported biological threats, and emerging biosafety technologies. ${ }^{49}$

It is until recently that various government authorities and scientific organizations have recognized the importance and need to improve biosafety to such an extent that in 2016, the Chinese government incorporated biosafety as a national security domain; In 2018, the United States issued the new National Biodefense Strategy, and the United Kingdom issued the Biological Safety Strategy. These strategies now include significant disease outbreaks, events precipitated by an accidental release of biological facilities, a deliberate biological attack, and animal or plant disease outbreaks with the potential to significantly impact the economy, the environment, and society. ${ }^{50}$

\section{Conclusion}

The term biosecurity has traditionally been used in agriculture, livestock, and at the laboratory level, focusing only on the workplace. The evolution of the term biosafety has allowed its users to be left only to the laboratory setting, now allowing to focus this term on the prevention and control of emerging infectious diseases, defensive action against attacks with biological weapons and bioterrorism, abuse of biotechnology, and of course, the protection of biosafety in the laboratory, with the understanding that these pathogens, when escaping from the laboratory, pose a risk to public health,

At the occupational health level, to establish protective measures in the transmission of infections, mainly nosocomial among health workers and the general public, several countries have developed guidelines for the control of these infections in health personnel, whose main objective is to identify and control the risks to which these personnel are exposed since these personnel are more likely than other groups to have work-related injuries or illnesses.

In Mexico, despite the existence of a legal framework and regulations that must be complied with by both health institutions and health personnel, it has been detected, as in other countries, that non-compliance and the lack of protective equipment personnel produces unfavorable consequences, alarmingly increasing infections associated with health care.

Infections Associated with Health Care contracted by health personnel in Mexico, should decrease significantly, through various strategies to disseminate the various regulations and laws, emphasizing minimizing exposure to various biological agents when counting the administrative processes, the infrastructure, and adequate personal protective equipment. Based on the evolution of the concept of biosafety, it is not feasible to currently use it in the workplace, since it is not a term found in the different codices, regulations, and laws, and reference must be made to the Health and Safety Standards at work. In the long term, it will be useful to analyze the possibility of including the term occupational biosecurity aimed at health personnel in Mexican regulations.

\section{References}

1. Haley RW, Culver DH, White JW, Morgan WM, Emori TG, Munn VP, et al. The efficacy of infection surveillance and control programs in preventing nosocomial infections in U.S. hospitals. Am J Epidemiol. 1985;121:182-205.

2. Measuring the prevalence of nosocomial infections in general hospitals of the main Public health institutions: Extensive documentary report [Internet]. Mexico: Health Secretary. 2011[Assessed on December 1, 2020] Available from: http://www.dged. salud.gob.mx/contenidos/dess/descargas/estudios_ especiales/NOSOCOMIAL_IF.pdf

3. Diario Oficial De La Federacion. Official Mexican Standard NOM-045-SSA2-2005 for epidemiological

surveillance, prevention and control of nosocomial infections [Internet]. Mexico: Diario Oficial De La Federacion; 2005 [Assessed on December 1, 2020]. Available from: http://www.dof.gob.mx/ normasOficiales/3896/salud/salud.htm

4. Centers for Disease Control. Prevention strategies for seasonal influenza in health care settings: Guidelines and Recommendations [Internet]. Centers for Disease Control; 2018[Assessed on December 1, 2020]. Available from: https://www.cdc.gov/flu/ professionals/infectioncontrol/healthcaresettings. $\mathrm{htm}$

5. Centers for Disease Control. Recommendations for prevention of HIV transmission in health-care settings[Internet]. MMWR. 1987[Assessed on 
December 1, 2020];36(suppl no. 2S). Available from: $\quad$ https://www.cdc.gov/mmwr/preview/ mmwrhtml/00023587.htm

6. General Directorate of Quality and Health Education, General Health Council Secretary of Integration and Development of the Health Sector, Health Secretary. Essential Actions for Patient Safety [Internet]. General Directorate of Quality and Health Education, General Health Council Secretary of Integration and Development of the Health Sector, Health Secretary. 2020 [Assessed on December 1, 2020]. Available from: http://www.calidad.salud.gob.mx/site/calidad/ docs/Acciones_Esenciales_Seguridad_Paciente.pdf

7. Agreen D. Understanding Mexican health worker COVID-19 deaths An Amnesty International report says that more health workers have died in Mexico than anywhere else. David Agren explores why. The Lancet. 2020;396;19:807.

8. Pan A, Liu L, Wang C, Guo H, Hao X, Wang Q et. al. Association of public health interventions with the epidemiology of COVID-19 outbreak in Wuhan, China. JAMA 2020; 323:1915- 23.

9. CDC COVID-19 Response Team. Characteristics of Health Care Personnel with COVID-19 - United States, February 12-April 9, 2020 [Internet]. MMWR Morb Mortal Wkly Rep. 2020 [Assessed on December 1, 2020];69:477-481. DOI: http://dx.doi. org/10.15585/mmwr.mm6915e6

10. Boccia S, Ricciardi W, loannidis JPA. What other countries can learn from Italy during the COVID-19 pandemic. JAMA Intern Med. 2020;180:927-8.

11. Whan D, Hu B, Hu C. Clinical Characteristics of 138 Hospitalized Patients With 2019 Novel CoronavirusInfected Pneumonia in Wuhan, China. JAMA. 2020;323(11):1061-1069.

12. Zhan M, Qin $Y$, Xue $X$, Zhu S. Death from COVID-19 of 23 health care workers in China. N Engl J Med. 2020;382:2267-8.

13. Guerrero Torres $L$, Caro vega $Y$, Crabtree Ramírez B, Sierra madero J.G. Clinical Characteristics and Mortality of Health-Care Workers with Severe Acute Respiratory Syndrome Coronavirus 2 (SARS-CoV-2) Infection in Mexico City. Clin Infect Dis. 2020;28:1465.

14. Gaudioso J, Astuto GL, M Salerno R. Biosecurity: progress and challenges. JALA. 2009;14:141-7.

15. Berns IK. Grand challenges for biosafety and biosecurity. Front Bioeng Biotechnol. 2014;2:35. DOI: 10.3389/fbioe.2014.00035

16. World Health Organization. Laboratory biosafety manual [Internet]. $3^{\text {rd }}$ ed. Geneva: World Health Organization. 2004 [Assessed on December 1, 2020]: pp.1-186. Available from: https://www.who. int/csr/resources/publications/biosafety/Biosafety 7 . pdf?ua=1

17. Hottes AK, Rusek B, Sharples F, Rapporteurs.
Biosecurity Challenges of the Global Expansion of High-Containment Biological Laboratories: Summary of a Workshop [Internet]. Washington: The National Academies Press; 2012 [Assessed on December 1, 2020]. Available from: https://www.nap.edu/ read/13315/chapter/1

18. Ma H, Zhu J, Liu J, Zhang X, Liu Y, Yang Q. Hospital biosecurity capacitation: Analysis and recommendations for the prevention and control of COVID-19. J Biosaf Biosecur. 2020;2(1):5-9.

19. Aguilar Elena R, González Sánchez J, Morchon R, Martínez Merino V. Biological safety or occupational biosafety? Gac Sanit. 2015;29(6):473.

20. World Trade Center. Cartagena Protocol on Biosafety of the Convention on Biological Diversity [Internet]. Montreal: World Trade Center; 2000 [Assessed on December 1, 2020]. Available from: https:// www.conacyt.gob.mx/cibiogem/images/cibiogem/ comunicacion/publicaciones/cartagena-protocol-es. pdf

21. Tarres Vives M. Biosafety and Technical Standards. Catalan Journal of Public Law. 2008;36:1-25.

22. Organization of the United Nations for Agriculture and Food (FAO). Instruments of the FAO above biosecurity [Internet]. Rome: FAO. 2007 [Assessed on December 1, 2020]:2-166. Available from: http:// www.fao.org/3/a-a1140s.pdf

23. Meyerson AL, Reaser KJ. Biosecurity: moving toward a comprehensive approach. Bioscience. 2002;52:593-600.

24. Nordmann DB. Issues in biosecurity and Biosafety. Int J Antimicrob Agents. 2010 Nov;36 Suppl 1:S66-9.

25. The National Association of State Departments of Agriculture Research Foundation. The Animal Health Safeguarding Review- Results and Recommendations 2001 [Internet]. Washington DC: The National Association of State Departments of Agriculture Research Foundation; October 2001 [Assessed on December 1, 2020]. Availabe from: http://the-seurity-institute.com/userfiles/file/ Animal\%20Health\%20Safeguarding\%20Review.pdf

26. European Standardization Committee, CEN. CEN Workshop Agreement- Laboratory Biorisk Management [Internet]. Brussels: European Standardization Committee. 2011 [Assessed on December 1, 2020];pp:1-46. Available from: https://mbdsbiosafety.net/doc/ LaboratoryBioriskManagementCWA15793.pdf

27. Zhou D, Song H, Wamg J, Li Z, Xu S, Ji X, et al. Short communication: Biosafety and biosecurity. J Biosaf Biosecur. 2019;1(1):15-8.

28. Ruiz M R, Méndez D.A. Public health problem: chronic kidney disease in Mexico, the urgent need to train specialist doctors. Gac Med Bilbao. 2018;115(4):194-9. 
29. Government of Mexico, Secretary of Constitution. Political Constitution of the United States MexicanLast Public Reform in the Official Directory of the Federation: 8 MAY 2020[Internet]. Mexico: Government of Mexico, Secretary of Constitution; 2020[Assessed on December 1, 2020]. Available from: http://www.ordenjuridico.gob.mx/Constitucion/ cn16.pdf

30. Chamber of Deputies of the h. Union Congress, Secretary General Secretary of Parliamentary Services. Federal Employment Law, New Law published in the Official Diary of the Federation on April 1, 1970 Vigent Text Last reform published DOF 12-06-2015 [Internet]. Mexico: CHAMBER OF DEPUTIES OF THE H. UNION CONGRESS, Secretary General Secretary of Parliamentary Services; 2015 [Assessed on December 1, 2020]. Available from: https://www.gob.mx/cms/uploads/ attachment/file/156203/1044_Ley_Federal_del_ Trabajo.pdf31. Secretary of Labor and Social Security. Federal Regulations on Safety and Health at Work [Internet]. Mexico: Secretary of Labor and Social Security; 2014 [Assessed on December 1, 2020]. Available from: http://www.diputados.gob.mx/ LeyesBiblio/regla/n152.pdf

32. Government of Mexico. Federal Law on Metrology and Standardization- New Law published in the Official Gazette of the Federation on July 1, 1992 Last reform published DOF 04-30-2009. Mexico: Government of Mexico; 2009. Available from: https:// www.gob.mx/cms/uploads/attachment/file/107522/ leyfederalsobremetrologiaynormalizacion.pdf

33. Secretary of Labor and Social Welfare Mexico. WHO ARE YOU? [Internet]. Mexico: Secretary of Labor and Social Welfare Mexico; 2014 [Assessed on December 1, 2020]. Available from http://www.stps. gob.mx/bp/secciones/conoce/quienes_somos/index. html

34. Secretary of labor and social security. Regulatory framework for occupational health and safety [Internet]. Mexico: Secretary of labor and social security; 2012 [Assessed on December 1, 2020]. Retrieved from: http://asinom.stps.gob.mx:8145/ Centro/CentroMarcoNormativo.aspx

35. Chamber of Deputies of the $\mathrm{H}$. Congress of the Union Secretary General Secretary of Parliamentary Services General Directorate of Libraries. Federal Regulations for Safety, Hygiene and Work Environment. (Last reform published on 01-28-1997) [Internet]. Mexico: Chamber of Deputies of the $\mathrm{H}$. Congress of the Union Secretary General Secretary of Parliamentary Services General Directorate of Libraries; 1997 [Assessed on December 1, 2020]. Available from: http://www.stps.gob.mx/bp/ secciones/dgsst/normatividad/n152.pdf

36. ISO. Occupational health and safety management systems- Requirements with guidance for use
[Internet]. First Eds. Mexico: ISO. 2018 [Assessed on December 1, 2020]:Pp.1-49. Available from: http:// ergosourcing.com.co/wp-content/uploads/2018/05/ iso-45001-norma-Internacional.pdf

37. Health Secretary. Procedures Manual of the Biosafety Committee [Internet]. Mexico: Health Secretary; 2015 [Assessed on December 1, 2020]. Retrieved from: http://www.hgm.salud.gob.mx/descargas/pdf/ dir_inv/ManProcComiteBioseguridad.pdf

38. Biosecurity committee, investigation center, regionales “Dr. Hideyo Noguchi”, Autonomo University of Yucatán. Basic protocol of Biosecurity [Internet]. Mexico: Autonomo University of Yucatán; November 2010 [Assessed on December 1, 2020]. Available from: http://transparencia.uady.mx/sitios/cirbiolo/ documentos_publicos/2017/Fracci\%C3\%B3n\%20 I\%20Marco\%20Normativo/Anexos/Protocolo $\% 20$ B\%C3\%A1sico\%20de\%20Bioseguridad.pdf

39. National Institute of Public Health. Biosafety Committee Internal Regulations of the Biosafety Committee [Internet]. Mexico: National Institute of Public Health; 2015 [Assessed on December 1, 2020]. Available from https://www.insp.mx/comitebioseguridad.html

40. Biosafety Committee. Integration and Operation Manual of the Biosafety Committee [Internet]. Ministry of Health National Institute of Respiratory Diseases Ismael Cosío Villegas. 2016[Assessed on December 1, 2020]. Available from: http://www. iner.salud.gob.mx/descargas/comitebioseguridad/ COMITEBIOSEGURIDAD_05122016.pdf

41. CIBIOGEM. Inter secretarial Commission for the Biosafety of Genetically Modified Organisms (CIBIOGEM) [Internet]. Mexico: CIBIOGEM. [Assessed on December 1, 2020]. Available from: https://www.conacyt.gob.mx/cibiogem/images/ cibiogem/comunicacion/divulgacion/SecretariaEjecutiva-06032018-web.pdf

42. Mexican Association of Biosafety A.C. The Mexican Association of Biosafety, A.C., through its Directive Council, manifests its position, by means of the following communication, on the initiative of Law of Humanities, Sciences and Technologies presented by Senator Ana Lilia Rivera [Internet]. Mexico City: Mexican Association of Biosafety A.C. 2019 [Assessed on December 1, 2020]. Available from: https://amexbio.wildapricot.org/resources/ Documents/AMEXBIO/CIBIOGEM\%20Postura\%20 AMEXBIO.pdf

43. Health Secretary, Government of Mexico. Platform for the National Network of Public Health Laboratories [Internet]. Mexico: Health Secretary, Government of Mexico; 2016 [Assessed on December 1, 2020]. Retrieved from: https://www.gob.mx/salud/accionesy-programas/plataforma-para-la-red-nacional-delaboratorios-de-salud-publica?state=published 
44. Gobierno of Mexico. Current Guidelines, National Network of Public Health Laboratories [Internet]. In: DRE Technical Publications Collection. Mexico: Gobierno of Mexico; 2020 [Assessed on December 1, 2020]. Available from: https://www.gob.mx/salud/ documentos/lineamientos-vigentes-red-nacional-delaboratorios-de-salud-publica?state=published

45. Campins M. C, Uriona T. S. General epidemiology of infections acquired by health personnel. Immunization of health personnel. Enferm Infecc Microbiol Clin. 2014;32 (4):259-65.

46. State Center for Epidemiological Surveillance and Disease Control. Cases and deaths in health personnel due to COVID-19- Region of the Americas 2020 week 38. Mexico: State Center for Epidemiological Surveillance and Disease Control. Available from: https://salud.edomex.gob.mx/cevece/ documentos/difusion/tripticos/2020/Semana38.pdf
47. SALUD, Secretary of State. COVID-19 MEXICO PHASE 3 Daily Technical Release Wednesday, November 4, 2020[Internet]. Mexico: Secretary of Health; November 2020[Assessed on December 1, 2020]. Availabe from: https://www.gob.mx/cms/ uploads/attachment/file/590377/CP_Salud_CTD_ coronavirus_COVID-19_04nov20.pdf

48. World Health Organization. COVID-19 Weekly Epidemiological Update Data as received by WHO from national authorities, as of 29 November 2020, 10 am CET[Internet]. World Health Organization; 2020 [Assessed on December 1, 2020]. Available from: https://www.who.int/publications/m/item/ weekly-epidemiological-update---1-december-2020

49. The First Global Biosafety Symposium in 2018 was held in Beijing. J Bios Biosec 2019;1(1):11.

50. Xu J, Yuan Z. Inaugural editorial: Towards evidencebased biosafety and biosecurity. J Bios Biosec. 2019;1(1):1-2. 